\title{
Sprogforståelse efter 20 år i Danmark: tolkning af anaforer i ledsætninger
}

\author{
DONNA ELEANOR PROHIC OG \\ ELISABETH ENGBERG-PEDERSEN
}

\begin{abstract}
Serbokroatisk har i modsætning til dansk nulsubjekter hvis subjektet i en sætning er koreferentielt med den foregående sætnings subjekt. Et pronominelt subjekt tolkes derfor i reglen som signal om at subjektets referent er skiftet, og at det pronominelle subjekt er koreferentielt med et andet led end subjektet i en tidligere sætning. Ved hjælp af en selvstyret læsetest (self-paced reading test) blev tolv serbokroatiske indvandrere som var kommet til Danmark efter at de var fyldt 15 år, og som havde boet mindst 23 år i Danmark, sammenlignet med tolv danskere med dansk som førstesprog. Forsøgsdeltagerne læste en helsætning med en final adverbiel ledsætning med et pronominelt subjekt som ud fra ledsætningens slutning skulle tolkes som koreferentielt med enten subjektet eller det oblikke led i oversætningen (Kvinden ${ }_{i}$ bilser på kassedamen, mens bun $n_{i}$ betaler for varerne på båndet vs. Kvinden ${ }_{i}$ hilser på kassedamen ${ }_{j}$, mens bun ${ }_{j}$ scanner varerne på båndet ind). Resultaterne viste det forventede mønster: Der var en interaktionseffekt mellem deltagertype (serbokroatisk eller dansk førstesprog) og korefentialitetstype (pronomen koreferentielt med oversætningens subjekt eller med dens oblikke led). Deltagerne med serbokroatisk baggrund læste det relevante område af sætningen signifikant langsommere når pronomenet skulle tolkes som koreferentielt med oversætningens subjekt, end når det skulle tolkes som koreferentielt med det oblikke led i oversætningen. Forskellen på de to kontekster var ikke signifikant for kontrolgruppen. I konklusionen peges der på betydningen af bevidsthed om de typologiske forskelle mellem dansk og de sprog som tales af voksne flygtninge og indvandrere som skal lære dansk.
\end{abstract}

EMNEORD: nulsubjekt, bestemmelse af anaforers reference, serbokroatisk, andetsprogsforståelse

\section{INDLEDNING}

Udlændinges dansk bedømmes næsten altid på deres sprogproduktion, og især udtalen spiller en stor rolle for hvor godt danskere synes at 
udlændinge taler dansk. Det er mere overset at sprogforståelsen selv efter mange år i Danmark kan være påvirket af udlændingenes førstesprog. Et af de træk som andetsprogsforskningen har fokuseret på, er forståelsen af subjektpronomener (Roberts et al. 2008; Keating et al. 2011). I mange sprog, de såkaldte pro-drop-sprog eller sprog med nulsubjekter, udelades subjektet $\mathrm{i}$ en ledsætning $\mathrm{i}$ reglen når det er koreferentielt med oversætningens subjekt, mens det $\mathrm{i}$ andre sprog som dansk er obligatorisk at have et subjekt $\mathrm{i}$ ledsætninger med et finit verbal uanset om subjektet er koreferentielt med oversætningens subjekt eller ej. I (1a) gør betaler det mest sandsynligt at bun er koreferentielt med kvinden i oversætningen, i (1b) tyder scanner på at bun skal tolkes som koreferentielt med præpositionsobjektet kassedamen i oversætningen. Men i begge tilfælde skal der være et subjekt i ledsætningen.

(1) a. Kvinden ${ }_{i}$ bilser på kassedamen, mens hun ${ }_{i}$ betaler for varerne på båndet.

b. Kvinden, bilser på kassedamen, mens bun, scanner varerne på båndet ind.

I et sprog med nulsubjekter som serbokroatisk (Leko 1989) udelades modsvarigheden til bun i (1a) med mindre leddet er emfatisk. Et eksplicit subjekt tolkes derfor normalt som koreferentielt med det oblikke led i oversætningen - eller som refererende til en helt tredje person. I (2a) fra serbokroatisk er subjektet udeladt i ledsætningen fordi det er koreferentielt med tata ('far') i oversætningen; subjekterne i begge sætninger henviser altså til samme referent. I (2b) viser det eksplicitte pronominelle subjekt (on 'han') at dette subjekt ikke er koreferentielt med oversætningens subjekt, og subjektet tolkes så som korefentielt med det oblikke led i oversætningen (sina 'søn'), i hvert fald i fraværet af en kontekst der peger på en helt tredje referent.

(2) a. Tata ${ }_{i}$ gleda u sina $a_{j}$ dok $\varnothing_{i}$ jede.

far se.3SG.PRS på søn.ACC mens spise.3SG.PRS

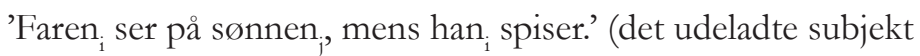
refererer til faren) 


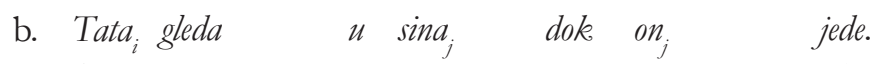

far se.3SG.PRS på søn.ACC mens 3SG.MASC spise.3SG.PRS 'Faren, ser på sønnen, mens han, spiser.' (on refererer sandsynligvis til sønnen)

Det betyder at man kan forvente at sprogbrugere med serbokroatisk som førstesprog er tilbøjelige til at tolke det eksplicitte subjekt i den danske sætning (1a) som koreferentielt med alt andet end subjektet $i$ oversætningen, i hvert fald indtil de hører eller læser verbalet.

De flygtninge med serbokroatisk baggrund der kom til Danmark i 1990'erne, har i dag været her i mindst 20 år og bruger dansk i deres dagligdag. Denne undersøgelse har til formål at afdække om disse sprogbrugere påvirkes af deres førstesprog $i$ tolkningen af danske pronominelle subjekter $\mathrm{i}$ efterstillede adverbielle ledsætninger som (1a-b).

Eftersom vi fokuserer på den rolle som forstesproget spiller for forståelse af andetsproget, og eftersom synet på førstesprogets rolle for andetsprogsindlæringen har varieret meget over de sidste 50-60 år, giver vi først et kort rids af denne udvikling. Dernæst gennemgår vi dele af litteraturen om processering af pronomener og nulsubjekter $i$ typologisk forskellige sprog. Efter disse to oversigter følger vores egen undersøgelse med en gennemgang af metoden og resultaterne, og til sidst diskuterer vi resultaterne $i$ lyset af hvad man ellers er nået frem til med hensyn til bestemmelse af pronomeners reference i den psykolingvistiske litteratur.

\section{UDVIKLINGEN I SYNET PÅ ANDETSPROGSINDLÆRING}

I 1950'erne var andetsprogsforskningen stærkt påvirket af Skinner og behaviorismen (Ellis 2015). Skinner (1957) fokuserede på adfærd og mente at sprogudøvelse ligesom al anden adfærd udgøres af vaner som opstår som respons på specifikke faktorer i vores omgivelser, bl.a. gennem imitation og forstærkning. Han mente også at gamle vaner hæmmer indlæringen af nye vaner. Det betyder at de først lærte sprogvaner står i vejen for nye. Den behavioristiske teori om sprog gav anledning til en af de tidligste modeller for tværsproglig overførsel, Lados kontrastanalyse (1957), som blev et vigtigt redskab for både undervisere og sprogindlærere fra 1950'erne til 1970'erne. Ifølge denne teo- 
ri påvirkes en persons sproglige kompetencer på andetsproget stærkt af vedkommendes førstesprog. De egenskaber som de to sprog har fælles, skaber mulighed for positiv overførsel og fremmer tilegnelsen af andetsproget, mens forskellene mellem første- og andetsproget giver negativ overførsel og sinker andetsprogstilegnelsen (fx Littlewood 1984). Kontrastanalysen gav anledning til forudsigelser om hvor den negative overførsel opstår (Geva 2014). Dvs. det var på disse områder at sprogunderviserne skulle anvende intensive teknikker for at overvinde interferens fra førstesproget og i stedet skabe nye sprogvaner (Banathy et al. 1966).

I den stærkeste version af kontrastanalysen hævdedes det at alle sprogfejl $\mathrm{i}$ andetsproget skyldtes den negative overførsel fra førstesproget. Ingen undersøgelser har dog kunnet bekræfte denne påstand, og den kontrastive analyse er blevet meget kritiseret for at overdrive overførsel (Abbas 1995). Mange forventede fejl, som burde opstå ifølge kontrastanalysen, forekommer ikke, og egentlige fejl er ofte uafhængige af strukturforskellene mellem sprogene og skyldes i stedet overgeneralisering eller andre mentale processer (Dulay et al. 1982).

Et andet belæg for at overførselsrelaterede fejl ikke er de eneste fejl blandt sprogbrugere der tilegner sig et andetsprog, er at mange af fejlene $i$ et og samme andetsprog laves af mennesker med vidt forskellige førstesprog (Bailey et al. 1974). Derfor kom der en modreaktion til de behavioristisk orienterede teorier om andetsprogstilegnelse. Dulay og Burt (1974) testede fx sprogbrugere med spansk som førstesprog og engelsk som andetsprog og fandt at $87 \%$ af deres fejl i engelsk lignede de fejl som børn laver på engelsk når de tilegner sig det som førstesprog. Kun knap $5 \%$ af fejlene skyldtes overførsel fra spansk til engelsk. Derfor brugte Dulay og Burt Univeral Grammar (UG) til at fremsætte den såkaldte identitetsteori, dvs. en teori om at andetsprogstilegnelsen foregår på samme måde som førstesprogstilegnelsen.

Krashen (1982) tilsluttede sig påstanden om at der findes en kritisk periode for sprogtilegnelse, som slutter med pubertetens start (Lenneberg 1967), og hævdede at der må skelnes mellem tilegnelse og indlæring. Tilegnelse indebærer en implicit og uformel måde at tilegne sig et sprog på svarende til det man ser hos børn før den kritiske periodes slutning, mens indlæring betegner den bevidste sprogindlæringspro- 
ces, hvor man gør en aktiv indsats for at lære sproget. Denne proces resulterer i en eksplicit viden om sprogets struktur, hvilket skaber en form for metasproglig forståelse. Krashen mente at man kunne forvente overførselsfejl især når sprogindlæringen foregik efter pubertetens start. Andre mente imidlertid at sprogbrugere har adgang til UG hele livet, og at deres fejl på andetsproget derfor i højere grad afspejler de træk som UG udpeger som mest grundlæggende i verdens sprog. Det var altså der hvor målsproget afveg fra de mest udbredte parameterindstillinger, at man måtte forvente fejl.

Blot fordi kontrastanalysen blev forkastet af tilhængerne af UG, forsvandt belæggene for overførsel mellem sprog ikke. Derfor blev opmærksomheden på ny rettet mod tværsproglig indflydelse (fx i antologierne Gass \& Selinker 1983 og Kellerman \& Sharwood Smith 1986 og monografien Odlin 1989) samtidig med at man forsøgte at bevare dele af identitetsteoriens resultater om universelle træk i tilegnelsen. I de nyeste teorier inddrages et samspil mellem viden om førstesproget og andre eksterne og interne faktorer. Ud over typologiske forskelle mellem førstesproget og andetsproget (jf. kontrastanalysen) og sproglige universalier (jf. identitetsteorien) nævner Ellis (2015) at også sprogbrugernes egen opfattelse af muligheden for overførsel fra førstesproget til andetsproget kan påvirke deres andetsprog. Desuden spiller det en rolle hvor meget sprogbrugerne er eksponeret for andetsproget, og endelig betyder helt individuelle faktorer meget. I dag ser man altså andetsprogstilegnelse som resultat af et meget komplekst samspil af faktorer.

Som nævnt $\mathrm{i}$ indledningen forventer vi at sprogbrugere med serbokroatisk baggrund vil være tilbøjelige til at overføre deres opfattelse af et eksplicit pronomen som signal om skift i subjektets reference fra serbokroatisk til dansk, i hvert fald hvis deres indlæring af dansk påbegyndtes efter pubertetens start. Der findes en række psykolingvistiske undersøgelser af hvordan sprogbrugere bestemmer et pronomens eller et nulsubjekts reference, både i sprog med nulsubjekter og i sprog der kræver et eksplicit subjekt, og både blandt førstesprogstalere og blandt andetsprogstalere. 


\section{BESTEMMELSE AF ANAFORERS REFERENCE I FØRSTESPROG OG ANDETSPROG}

I Givóns hierarki for topicsammenhæng (topic continuity) (1983) er nulsubjekter det udtrykstræk der signalerer stærkest topicsammenhæng. Det kendes fra dansk ved det andet eller senere af flere sideordnede verbaler (Faren ser på sonnen og Ø rakker ham et cable). Forskellen på dansk og serbokroatisk er altså at denne mulighed, nulsubjekt, findes i en efterstillet adverbiel ledsætning på serbokroatisk, men ikke på dansk; på dansk rykker man nødvendigvis et trin ned i Givóns hierarki til et trykløst pronomen når man skifter til en ledsætning som i (1a-b).

Psykolingvistiske undersøgelser har forsøgt at afdække hvilke faktorer der styrer bestemmelse af anaforers reference (anaphora resolution), altså bestemmelsen af hvilket nominal en pronominel anafor er koreferentiel med (for en oversigt, se de la Fuente et al. 2016). Hemforth et al. (2010) sammenlignede bestemmelse af anaforers reference i finale 'før'-sætninger i engelsk, tysk og fransk. I en tysk sætning som sætningen i (3) kan relationen mellem oversætningens og ledsætningens referentielle led kun udtrykkes på én måde, nemlig med en eksplicit anafor, og her er der overvældende sandsynlighed for at anaforen tolkes som koreferentiel med oversætningens subjekt.

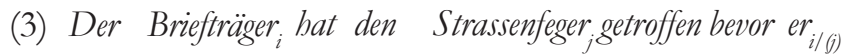
ART postbud har ART gadefejer mødt før han til hjem gik 'Postbuddet ${ }_{i}$ mødte gadefejeren, før han ${ }_{i /())}$ gik hjem'

I fransk er der to syntaktiske muligheder, nemlig en med anafor og finit verbal som i (4a) og en med nulsubjekt og infinit verbal som i (4b). 
(4) a. Le facteur $r_{i}$ a rencontré le balayeur ${ }_{j}$ avant qu'il $l_{(j) / j}$ ART postbud har mødt ART gadefejer før at-han rentre à la maison. går til ART hus

'Postbuddet ${ }_{i}$ mødte gadefejeren, før han ${ }_{(\mathrm{i}) / \mathrm{j}}$ gik hjem'

b. Le facteur $r_{i}$ a rencontré le balayeur ${ }_{j}$ avant de $\varnothing_{\mathrm{i}}$ ART postbud har mødt ART gadefejer før PRÆP

\author{
rentrer à la maison. \\ gå til ART hus

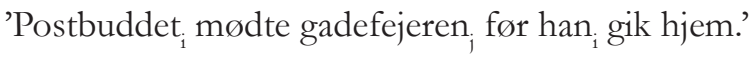

I (4a) med eksplicit anafor er forsøgsdeltagerne tilbøjelige til at tolke anaforen som koreferentiel med objektet i oversætningen, og Hemforth et al. (2010) tolker dette resultat som udtryk for en griceansk bestemt tilbøjelighed til at antage at taleren ville have valgt den entydige form uden subjekt (4b) hvis det andet prædikat handlede om samme referent som oversætningens subjekt (Grices mådesmaksime: 'Be brief!'). Da taleren ikke har valgt formen med nulsubjekt i (4a), må det være fordi anaforen er koreferentiel med oversætningens objekt.

Engelsk har også både en form med anafor og finit verbal og en form med nulsubjekt og infinit verbal, nemlig (5a) og (5b).

(5) a. The postman met the streetsweeper ${ }_{j}$ before he $e_{i /(j)}$ went home.

b. The postman ${ }_{i}$ met the streetsweeper ${ }_{j}$ before $\varnothing_{\mathrm{i}}$ going home.

Her fandt Hemforth et al. (2010) alligevel at forsøgsdeltagerne foretrak at tolke anaforen som koreferentiel med oversætningens subjekt selv når der var en eksplicit anafor som i (5a), omend ikke helt så hyppigt som de tysktalende forsøgsdeltagere. Da der findes et alternativ med nulsubjekt i engelsk, nemlig (5b), kan det undre at de engelsktalende deltagere ikke foretrak at tolke anaforen $\mathrm{i}(5 \mathrm{a})$ som koreferentiel med objektet i oversætningen $\mathrm{i}$ lighed med franske deltageres tolkning af (4a). Hemforth et al. (2010) peger på at den engelske konstruktion med before going home i (5b) er mindre frekvent end den franske konstruktion uden eksplicit anafor, avant de rentrer à la maison i (4b). De 
mener at Grices mådesmaksime ikke i så høj grad kommer i spil ved tolkningen af (5a) som ved tolkningen af (4a) på grund af den lavere frekvens af (5b). Derfor foretrak de fleste engelske forsøgsdeltagere at tolke den eksplicitte anafor i (5a) som koreferentiel med oversætningens subjekt.

Spørgsmålet er så hvorfor man på fransk hyppigere producerer formen med infinit verbal end på engelsk når der er tale om koreferentialitet mellem oversætningens og ledsætnings subjekter. Hemforth et al. (2010) forsøger at besvare dette spørgsmål ved hjælp af den kendsgerning at forskellige franske konjunktioner kombineres med enten indikativ eller konjunktiv i ledsætningen. Ved at bruge en infinit form undgår taleren hvad Hemforth et al. anser for en ekstra kognitiv belastning, nemlig at skulle holde styr på om verbalet skal være i indikativ eller konjunktiv. Denne forklaring på den franske præference for at tolke en eksplicit anafor som koreferentiel med objektet tager altså udgangspunkt $\mathrm{i}$ at den kognitive belastning ved at skulle holde styr på indikativ og konjunktiv fører til højere frekvens af konstruktioner med nulsubjekt og infinit verbal, og antager at det er frekvens der styrer modtagernes afkodningsforventninger om at anafor er tegn på skift i reference, og dermed på at anaforen er koreferentiel med objektet i oversætningen. Forklaringen bygger imidlertid på en præmis om at det er mest oplagt at have en anafor i ledsætninger, og at anaforen er koreferentiel med subjektet. Men så bliver det uforklarligt hvorfor nogle sprog har nulanafor som deres foretrukne form når der er tale om koreferentialitet med oversætningens subjekt; med andre ord, hvorfor skulle serbokroatiske talere foretrække helt at udelade anaforen?

En række undersøgelser har fokuseret på hvordan subjektpronomener og nulsubjekter tolkes i sprog med nulsubjekter som italiensk og spansk. Carminati (2002) fandt at i italienske sætninger som (6a) tolkede forsøgsdeltagere i $80 \%$ af tilfældene nulsubjektet som koreferentielt med subjektet i oversætningen, men kun i $20 \%$ af tilfældene tolkede de en eksplicit pronominel anafor (jf. (6b)) som koreferentiel med subjektet i oversætningen. Der var med andre ord en stærk præference for nul når subjekterne for de to handlinger var koreferentielle, og for et eksplicit pronomen når der var skift i reference. 
(6)

a. Marta scriveva frequentemente a Piera $_{j}$ quando $\varnothing_{i /(j)}$ era
Marta ${ }_{\mathrm{i}}$ skrev ofte
negli Stati Uniti.

Ifølge Runner og Ibarra (2016) fandt de la Fuente og Hemforth (2013) den samme fordeling af præferencer $i$ tilsvarende spanske sætninger, men lidt mindre udtalt: Ved nulsubjekt i ledsætningen blev oversætningens subjekt foretrukket som koreferentielt led i $65 \%$ af tilfældene, ved eksplicit pronominel anafor i godt $30 \%$ af tilfældene. Noget tyder altså på at nulsubjekter og anaforer ikke processeres ens i alle sprog med nulsubjekter.

Bestemmelse af anaforers reference er også blevet undersøgt blandt andetsprogsindlærere, og her er især en undersøgelse af Roberts et al. (2008) relevant for vores formål. Roberts et al. rejser spørgsmålet om det er strukturelle forskelle mellem sprogindlærernes førstesprog og deres andetsprog der gør at de processerer sætninger på andetsproget langsommere end førstesprogstalere, eller om det generelt er den kognitive belastning ved at processere et andetsprog der gør dem langsommere. I det sidste tilfælde skulle andetsprogsindlærere af et sprog uden nulsubjekter være lige dårligt stillet uanset deres førstesprogs struktur. Derfor undersøgte de forståelsen af pronomener i hollandsk hos sprogbrugere med enten tyrkisk eller tysk som førstesprog. Til forskel fra tysk og hollandsk er tyrkisk et sprog med nulsubjekter. Det vil sige at forsøgsdeltagerne med tysk baggrund skulle have en strukturel fordel sammenlignet med deltagerne med tyrkisk baggrund ved forståelsen af pronomener på hollandsk.

Roberts et al. (2008) brugte bl.a. et eksperiment med eyetracking til at belyse deltagernes onlineprocessering og et spørgeskema til at vise hvilken referent deltagerne foretrak som koreferentiel med en anafor. 
Den relevante forsøgsbetingelse for vores undersøgelse var sekvenser som den hollandske modsvarighed til Peter og Hans er på kontoret. Mens Peter arbejder, spiser han en sandwich. Det er en stille dag. Her introduceres to referenter i den første helsætning; så kommer der en helsætning med en initial adverbialsætning med den ene af referenterne som subjekt og en oversætning med en anafor. I eksemplet kan han i oversætningen tolkes som koreferentielt med det helsætningsinterne subjekt Peter i ledsætningen eller med det andet led i den første helsætning, Hans. Hvis deltagere med tyrkisk baggrund påvirkes af muligheden for nulsubjekter i tyrkisk, vil de tolke den hollandske modsvarighed til han som koreferentielt med Hans snarere end Peter, mens deltagere med tysk baggrund kan forventes at følge det samme mønster som deltagere med hollandsk som førstesprog, dvs. de vil vælge Peter som referent for anaforen fordi Peter nævnes i samme helsætning og tilmed som subjekt.

I overensstemmelse med de typologisk bestemte forventninger viste Roberts et al.s (2008) spørgeskemaundersøgelse at deltagerne med tyrkisk baggrund signifikant oftere valgte referenten i den foregående helsætning som referent for anaforen end de to andre sproggrupper. Til gengæld viste eyetracking-eksperimentet at de to andetsprogsgrupper begge så længere tid på det problematiske område af sætningen (pronomenet og det efterfølgende verbal) end førstesprogstalerne på trods af at man kunne forvente at deltagerne med tyrkisk baggrund uden tøven ville forstå det eksplicitte pronomen som koreferentielt med det helsætningseksterne nomen (Hans i eksemplet), og at deltagerne med tysk som baggrund uden tøven ville tolke anaforen som koreferentiel med subjektet $\mathrm{i}$ ledsætningen $\mathrm{i}$ lighed med de hollandsktalende deltagere. Deltagernes specielle tyrkiske baggrund slog altså kun igennem i offlineundersøgelsen af deres forståelse af sætningerne. Ved undersøgelse af deres onlineprocessering i eyetracking-eksperimentet viste de to andetsprogsgrupper det samme belastningsmønster uanset deres førstesprog. Roberts et al. (2008) mener at både diskursprominens og syntaktiske træk peger mod Peter som anaforens referent i eksemplet, men syntaktisk set kunne Hans også være referenten. Derfor skal andetsprogstalerne bruge tid på at integrere diskursprominens og syntaks. Roberts et al.s konklusion er at " [t]he observed problem is [...] 
caused by syntax and must be resolved by pragmatics, and it is at the level of pragmatics that the L1 appears to exert its influence" (2008: 352-353).

Serbokroatisk er som nævnt et sprog med nulsubjekter, men selv når et subjekt $\mathrm{i}$ en ledsætning er koreferentielt med oversætningens subjekt, er der alternative konstruktionsmuligheder, idet der forekommer sætninger med emfatiske pronomener. Desværre har vi ingen mulighed for at undersøge frekvensen af de alternative konstruktioner eller hvor ofte en anafor i serbokroatisk er koreferentiel med et forudgående subjekt, og hvor ofte den er koreferentiel med et andet led. Det forsøg som vi gør rede for herunder, ligner Roberts et al.s (2008) forsøg derved at vi undersøger onlineprocesseringen af et pronomen, dog ved en selvstyret læsetest (self-paced reading test) og ikke ved eyetracking. Men i modsætning til sætningerne i Roberts et al. (2008) bruger vi kun helsætninger med finale adverbielle ledsætninger, og det problematiske pronomen findes i ledsætningen. Sætningerne i Roberts et al. (2008) er påfaldende ved at have et proprium i den initiale ledsætning og anaforen i oversætningen (i dansk oversættelse: 'Mens Peter arbejder, spiser han en sandwich'); det kan give anledning til et ekstra problem med integrering af syntaktisk og pragmatisk information. I vores sætninger sandsynliggøres en bestemt tolkning af den pronominelle anafor gennem den del af sætningen der følger efter anaforen. Det betyder at en forsinkelse i læsningen efter anaforen kan tolkes som udtryk for brud på læserens spontane tolkning af anaforen. Vi forventer altså at sprogbrugere med serbokroatisk baggrund anvender en tolkningsstrategi der ligner den man har fundet $\mathrm{i}$ andre sprog med nulsubjekter (Carminati 2002; de la Fuente og Hemforth 2013), og at de overfører den fra deres førstesprog serbokroatisk til dansk. Det betyder at de kan forventes at tolke pronomenet i en adverbiel ledsætning som i (1a) som en markør for skift i reference og at fastlægge anaforen som koreferentiel med det led der ikke er subjekt i oversætningen. Med hensyn til de danske deltagere forventer vi at de følger det mønster man har set hos fx tysktalende (Hemforth et al. 2010), nemlig spontant at tolke anaforen som koreferentiel med oversætningens subjekt når der ikke er noget i oversætningen der skaber andre forventninger (jf. Miltsakaki 2002). 


\section{METODE}

Formålet med undersøgelsen er som nævnt at finde ud af om talere af dansk med serbokroatisk baggrund overfører tolkningsstrategier for bestemmelse af anaforers reference fra deres førstesprog til deres andetsprog dansk. Som det er fremgået af indledningen, har man brugt en række forskellige metoder til at undersøge bestemmelse af pronomeners referencer, bl.a. selvstyrede læsetest, eyetracking og spørgeskemaer (Roberts et al. 2008; Hemforth et al. 2010). Ved en selvstyret læsetest ser forsøgsdeltagerne et ord i en tekst eller sætning et ord ad gangen på en skærm og klikker selv for at få næste ord frem. Langsommere læsning udtrykt ved længere mellem klikkene tolkes som udtryk for at teksten ikke opfylder de forventninger som læseren har dannet på baggrund af teksten indtil det punkt hvor læsningen forsinkes. Vi forventer at se en længere læsetid for talere med serbokroatisk baggrund i de sætninger hvor anaforen i den finale ledsætning er koreferentiel med subjektet i oversætningen, end i de sætninger hvor den er koreferentiel med det oblikke led, fordi teksten på serbokroatisk kun ville have en eksplicit anafor i ledsætningen hvis den var koreferentiel med det oblikke led eller henviste til en helt tredje referent.

To forsøgsgrupper deltog i undersøgelsen, en gruppe med serbokroatisk som førstesprog og dansk som andetsprog og en gruppe med dansk som førstesprog. For at sikre at deltagerne med serbokroatisk førstesprog havde et solidt kendskab til serbokroatisk og havde lært dette sprog først og ikke parallelt med dansk, valgte vi serbokroatiske indvandrere til Danmark der var mindst 15 år da de begyndte at lære dansk. Det betød at de var over den antagne kritiske alder for sprogindlæring ved mødet med dansk. På den anden side skulle deltagerne have et solidt kendskab til dansk, og vi valgte derfor deltagere der havde boet i Danmark i mindst 20 år. Faktisk var de alle ankommet for mindst 23 år siden, hvilket er omkring det tidspunkt hvor den sidste bølge af krigsflygtninge fra eks-Jugoslavien kom til Danmark. Den eksperimentelle gruppe består altså af tosprogede talere med serbokroatisk som førstesprog og dansk som andetsprog som har lært dansk efter 15-års-alderen og på undersøgelsestidspunktet havde boet i Danmark i mindst 23 år.

Kontrolgruppen bestod af talere med dansk som førstesprog. De 
var alle opvokset med udelukkende dansk i hjemmet. Selvom de har lært engelsk og eventuelt andre sprog i og udenfor skolen, forventede vi ikke at det ville betyde noget, dels fordi deltagernes førstesprog entydigt var dansk, dels fordi engelsk og andre skolesprog i Danmark heller ikke er sprog med nulsubjekter. For at kontrolgruppen skulle ligne gruppen med serbokroatisk baggrund så meget som muligt, var deltagerne fra samme aldersgruppe (40 til 70 år) og fra samme område i Danmark, nemlig København og omegn. Tabel 1 viser en oversigt over antallet af personer i hver gruppe, den gennemsnitlige alder, minimums- og maksimumsalderen samt den gennemsnitlige alder ved ankomsten til Danmark for den serbokroatiske gruppes vedkommende.

TABEL 1. DELTAGERE

\begin{tabular}{lccccc}
\hline & Antal & $\begin{array}{c}\text { Gennemsnits- } \\
\text { alder }\end{array}$ & $\begin{array}{c}\text { Min. } \\
\text { alder }\end{array}$ & $\begin{array}{c}\text { Max. } \\
\text { alder }\end{array}$ & $\begin{array}{c}\text { Gennemsnitlig } \\
\text { alder ved ankomst } \\
\text { til Danmark }\end{array}$ \\
\hline $\begin{array}{l}\text { Serbokroatisk } \\
\text { baggrund }\end{array}$ & 12 & 54 & 40 & 70 & 32 \\
\hline $\begin{array}{l}\text { Dansk } \\
\text { baggrund }\end{array}$ & 12 & 52 & 41 & 68 & - \\
\hline
\end{tabular}

Antallet af deltagere, deres alder og for deltagerne med serbokroatisk baggrund, deres gennemsnitsalder ved ankomst til Danmark.

Testen bestod af 70 sætninger (20 målsætninger, se bilag, og 50 fyldsætninger) med et efterfølgende forståelsesspørgsmål for hver sætning. Målsætningerne bestod af en oversætning med en final ledsætning indledt af mens som i (7):

\section{(7) Faren ${ }_{i}$ vinker til sonnen, mens han ${ }_{i}$ korer forbi legepladsen.}

Det temporale mens er så neutralt at der vanskeligt kan tolkes nogen kausal relation eller andet ind i forholdet mellem oversætning og ledsætning (jf. Miltsakaki 2002). Oversætningen indeholdt et subjekt og et oblikt led (et objekt, et præpositionsobjekt og i et tilfælde styrelsen for en præposition), mens ledsætningen indeholdt et pronomen som var søgt gjort koreferentielt med enten subjektet eller det oblikke led i oversætningen gennem betydningen af prædikatet efter anaforen (se 
bilaget). Hver sætning med en anafor der var koreferentiel med subjektet i oversætningen, havde en modsvarighed med en anafor i ledsætningen der var koreferentiel med det oblikke led. De to sætninger i et par adskilte sig kun ved ledsætningens prædikat. Et eksempel er (1), som gentages her.

(1) a. Subjektkoreferentiel variant: Kvinden, bilser på kassedamen, mens bun ${ }_{i}$ betaler for varerne på båndet.

b. Oblikkoreferentiel variant: Kvinden ${ }_{i}$ bilser på kassedamen, mens bun scanner varerne på båndet ind.

Hver deltager blev kun præsenteret for en af sætningerne fra hvert sætningspar. Dvs. halvdelen af deltagerne fra hver sproggruppe så en variant af testen med den ene ledsætning efter oversætningen, mens den anden halvdel så en variant med den anden ledsætning efter oversætningen. I hver testvariant indgik der ti subjektkoreferentielle sætninger og ti oblikkoreferentielle sætninger. Mellem hver målsætning var der to eller tre fyldsætninger. De adskilte sig fra målsætningerne med hensyn til sætningstype da deres funktion netop var at undgå at deltagerne gennemskuede strukturen i målsætningerne. Et eksempel på en fyldsætning kan ses i (8).

(8) Ejeren prover at holde biografen i live både kunstnerisk og okonomisk.

Sætningerne blev præsenteret for deltagerne et ord ad gangen midt på en skærm, dvs. hvert ord forsvandt når et nyt ord blev klikket frem. Et punktum efter det sidste ord viste slutningen på en sætning. Efter hver sætning fulgte et forståelsesspørgsmål. Forståelsesspørgsmålene var simple spørgsmål om handlingen i sætningerne og havde det formål at sikre at deltagerne ikke bare læste sætningerne, men også forstod dem. Deltageren fik to svarmuligheder, en i venstre side af skærmen, som skulle vælges med venstre piletast, og en anden i højre side, som skulle vælges med højre piletast. Det korrekte svars position på skærmen var randomiseret så det ikke altid stod i fx højre side. (9) viser et eksempel på et spørgsmål og de tilsvarende svarmuligheder: 
$50 \%$ af spørgsmålene handlede om oversætningen, og de andre $50 \%$ om ledsætningen, så deltagernes opmærksom blev ligeligt fordelt under testen og de ikke indstillede sig på kun at fokusere på den ene af sætningerne. Svarenes korrekthed afhang altså ikke nødvendigvis af hvordan deltagerne tolkede anaforen i ledsætningen, og derfor kan svarene ikke bruges til at bestemme denne tolkning. Målsætningerne blev vist $\mathrm{i}$ tre forskellige rækkefølger; formålet med det var at undgå at den træthed hos deltagerne som man kan forvente sidst i testen, ramte de samme sætninger i alle tilfælde. Testen blev lavet i PsychoPy2 (Peirce 2009) på en MacBook.

Ved forsøgets start blev deltagerne præsenteret for testen og instrueret i hvilke taster de skulle bruge, så de kunne sidde klar uden at skulle flytte hånden frem og tilbage mellem tasterne. De blev trænet på tre sætninger med forståelsesspørgsmål for at sikre at de forstod instrukserne. Der blev ikke givet feedback på om et svar var rigtigt eller forkert.

Testen forløb uden væsentlige problemer for nogen af deltagerne. Selv om nogle var længere tid om at fuldføre testen end andre (varighed 12-30 minutter), havde deltagerne nogenlunde lige mange fejl i deres besvarelser. De fleste havde 1-3 forkerte svar bortset fra en enkelt deltager - en serbokroatisk mand - som havde et fejlfrit resultat. Der var intet der tydede på at nogle enkelte sætninger genererede flere fejl end andre.

I starten af testen fulgte alle deltagerne instrukserne, men enkelte deltagere glemte dem senere og brugte kun den ene hånd til at trykke på tasterne. Det har dog ikke nogen betydning for resultaterne da et skift mellem tasterne under alle omstændigheder kun var påkrævet ved svarene på forståelsesspørgsmålene og ikke under den del af sætningen der er relevant for testresultaterne.

En enkelt serbokroatisk deltager læste sætningerne højt i begyndelsen, mens en anden serbokroatisk deltager havde lidt svært ved at læse nogle af de længere ord som grasslamaskine og andelsboligforening og læste dem højt for at forstå dem. De fleste deltagere gav udtryk for at det var en sjov test, og mange var interesserede $\mathrm{i}$ at få at vide hvor mange 
korrekte svar de havde. Nogle deltagere mente dog også at testen var ret trættende mod slutningen. Ingen af deltagerne kunne gennemskue formålet med testen, og flere af dem troede at vi var interesserede i svarene på spørgsmålene.

\section{RESULTATER}

Hypotesen var at sammenlignet med de rent dansksprogede deltagere ville deltagere med serbokroatisk baggrund have længere reaktionstid efter en pronominel anafor der viste sig at være koreferentiel med subjektet i oversætningen, end efter en pronominel anafor der viste sig at være koreferentiel med oversætningens oblikke led (dvs. ved skift i reference mellem de to subjekter). Grunden til denne antagelse er at deltagerne med serbokroatisk baggrund må antages at forvente at et pronominelt subjekt markerer et skift i reference. Ud fra undersøgelser af førstesprogstalere af andre sprog med eksplicitte subjekter (fx Hemforth et al. 2010) forventede vi at deltagerne med dansk som førstesprog spontant ville tolke anaforen som koreferentiel med oversætningens subjekt og derfor ville have forsinket læsning i de sætninger hvor resten af ledsætningen viste at pronomenet snarere var koreferentielt med det oblikke led i oversætningen.

Ved udregning af resultaterne frasorterede vi alle målinger hvor deltagerne svarede forkert på kontrolspørgsmålet efter en sætning. Det drejer sig om 6,9\% af alle svar (16 i gruppen med serbokroatisk som førstesprog, 17 i gruppen med dansk som førstesprog). Desuden er svarene for en sætning af hver type bortkommet for en deltager med dansk som baggrund. Beregningerne er altså $\mathrm{i}$ alt lavet på grundlag af reaktionstider i 445 sætninger.

Derefter isolerede vi reaktionstiderne fra det punkt hvor deltagerne trykkede på knappen efter ledsætningens pronominelle subjekt, til det punkt hvor de trykkede på knappen efter det andet ord efter verbalet. Dette tal er reaktionstiden for den pågældende læser af det relevante område i den pågældende sætning. I sætningen Kvinden hilser på kassedamen, mens hun betaler for varerne på båndet drejer det sig altså om den samlede læsetid fra deltageren trykker på knappen efter at have set bun, til og med der hvor deltageren trykker på knappen efter varerne. Vi inddrager med andre ord ikke læsning af selve pronomenet i reak- 
tionstiden da forsøgsdeltagerne ikke har nogen grund til at tøve når de bare ser bun på skærmen. Grunden til at vi inddrager flere ord efter pronomenet, er dels at det ikke i alle tilfælde er verbalet alene der gør subjektet entydigt, dels at læsere $\mathrm{i}$ reglen først forsinkes i læsningen lidt efter problemkilden, dvs. lidt efter det punkt $\mathrm{i}$ teksten der får dem til at undre sig. Vi udregnede så den gennemsnitlige reaktionstid for hver enkelt deltager for hver sætningstype, subjektkoreferentielle sætninger og oblikkoreferentielle sætninger, og det er altså disse gennemsnitstal for hver deltager der indgår i de statistiske beregninger.

Fordelingen af hver gruppes gennemsnitlige reaktionstider på de to sætningstyper fremgår af tabel 2.

TABEL 2. GENNEMSNITLIG REAKTIONSTID

\begin{tabular}{llll}
\hline Gruppe & Sætningstype & $\begin{array}{l}\text { Gennemsnitlig } \\
\text { reaktionstid i } \\
\text { millisekunder }\end{array}$ & $\begin{array}{l}\text { Standard- } \\
\text { afvigelse }\end{array}$ \\
\hline Serbokroatisk $(\mathrm{N}=12)$ & subjektkoreferentiel & 2447 & 555 \\
\hline & objektkoreferentiel & 2144 & 487 \\
\hline Dansk $(\mathrm{N}=12)$ & subjektkoreferentiel & 1588 & 382 \\
\hline & objektkoreferentiel & 1684 & 431 \\
\hline
\end{tabular}

Den gennemsnitlige reaktionstid for hver sætningstype inden for hver sproggruppe.

En ANOVA-test (af typen mixed between-within subjects beregnet på gennemsnittet af hvert individs reaktionstider inden for hver betingelse, subjektkoreferentiel og objektkoreferentiel) viste at der var en interaktion mellem sproggruppe og sætningstype med hensyn til reaktionstiderne $\mathrm{i}$ de to forsøgsbetingelser (Wilk's Lambda $=0,58, F(2,21)=$ $16,20, p=0,001, \eta^{2}=0,42$ ) (se figur 1). 


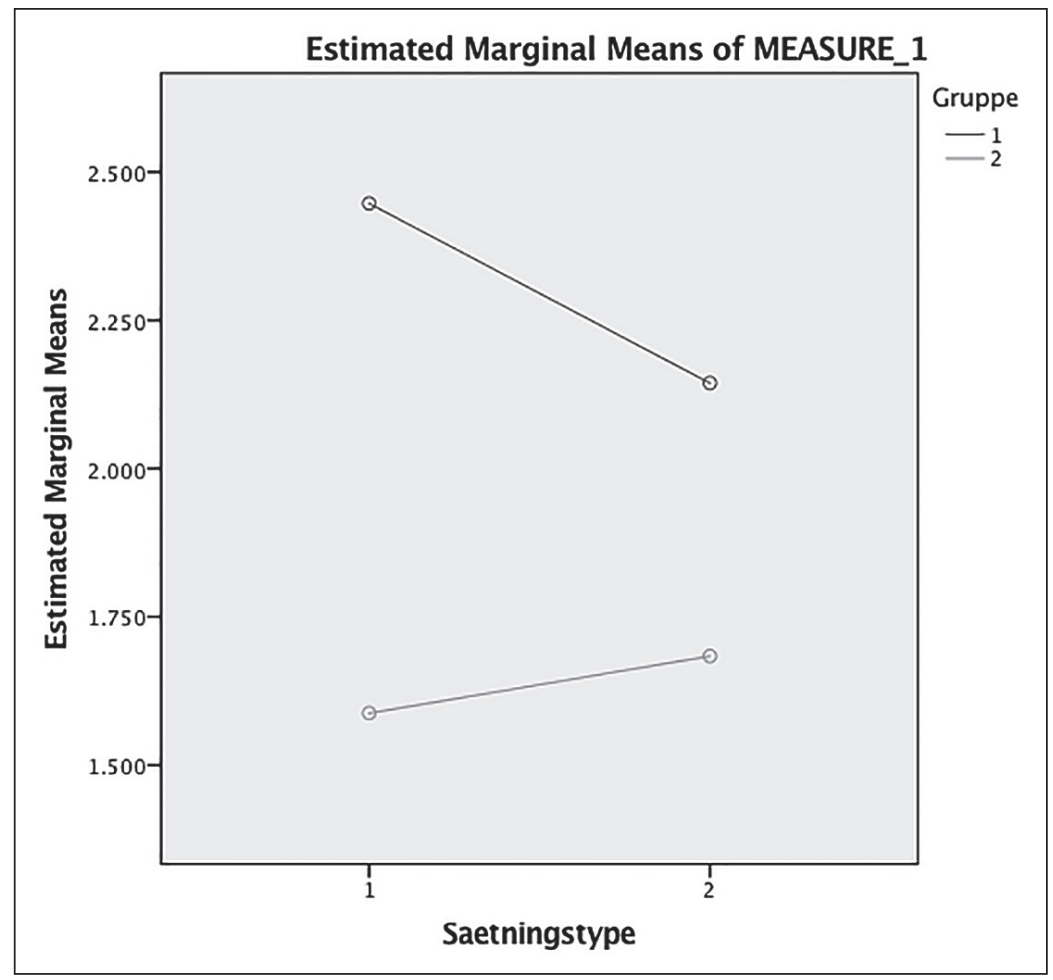

Sproggruppe 1 er deltagerne med serbokroatisk baggrund, sproggruppe 2 er deltagerne med dansk som førstesprog. Sætningstype 1 er sætninger hvor ledsætningens subjekt er koreferentielt med oversætningens subjekt, og sætningstype 2 er sætninger hvor ledsætningens subjekt er koreferentielt med oversætningens oblikke led.

Af figur 1 og tabel 2 fremgår det at deltagere med serbokroatisk baggrund havde længere reaktionstid på sætninger hvor subjektet $i$ ledsætningen var koreferentielt med subjektet $\mathrm{i}$ oversætningen, end deltagere med dansk som førstesprog, og at de også havde længere reaktionstid på sætninger hvor der var koreferentialitet mellem ledsætningens subjekt og det oblikke led i oversætningen, men at deres reaktionstid på denne type sætninger var kortere end for sætninger af type 1. Omvendt var deltagerne med dansk som førstesprog længere om at læse sætninger af type 2 end af type 1 . En t-test med sammen- 
ligning af den gennemsnitlige reaktionstid på hver af de to sætningstyper inden for hver sproggruppe viste med Bonferroni-korrigeret alfa-niveau på 0,0083 en signifikant forskel på forsøgsbetingelserne med en stor effekt i den serbokroatiske gruppe (serbokroatisk: $t(11)=$ $3,52, p<0,005, r=0,73)$. I den dansksprogede gruppe var forskellen ikke signifikant $(t(11)=1,96, p=0,08, r=0,51)$. Det betyder altså at der var en klar forskel på reaktionstiderne mellem de to sætningstyper inden for den serbokroatiske gruppe, og forskellen var i den forventede retning: Deltagerne med serbokroatisk baggrund reagerede signifikant langsommere på sætninger med et pronominelt subjekt der var koreferentielt med oversætningens subjekt, end på sætninger hvor det pronominelle subjekt $\mathrm{i}$ ledsætningen var koreferentielt med det oblikke led i oversætningen. For de rent dansksprogede deltagere kan vi ikke afgøre om et større antal deltagere og eventuelt flere sætninger i testen ville have vist den forventede forskel, nemlig at de ville læse sætninger hvor subjektet er koreferentielt med oversætningens oblikke led, langsommere end sætninger hvor subjektet er koreferentielt med oversætningens subjekt.

\section{DISKUSSION}

I serbokroatisk udelades et subjekt i en ledsætning der er koreferentielt med oversætningens subjekt som nævnt som hovedregel, mens sådan et subjekt er obligatorisk i dansk. Hvis ledsætningens subjekt er koreferentielt med et andet led end oversætningens subjekt, udtrykkes det eksplicit på serbokroatisk. Derfor var undersøgelsens hypotese at forsøgsdeltagere med serbokroatisk baggrund i udgangspunktet havde en forventning om at et eksplicit subjekt $i$ en efterstillet ledsætning på dansk er koreferentielt med det oblikke led i oversætningen. Det ville betyde at de blev forsinket $\mathrm{i}$ læsningen når denne forventning blev skuffet af anaforens verbal eller et senere led. Denne hypotese blev bekræftet idet forsøgsdeltagerne med serbokroatisk baggrund læste sætningerne med koreferentialitet mellem ledsætningens og oversætningens subjekter signifikant langsommere end sætningerne med koreferentialitet mellem ledsætningens subjekt og oversætningens oblikke led. På trods af at alle deltagere med serbokroatisk baggrund havde boet i Danmark i mindst 23 år, og alle taler dansk i deres dagligdag, slog 
deres førstesprog altså igennem i en lille forsinkelse i deres læsehastighed - dvs. som en lille forsinkelse i deres læseforståelse.

For de deltagere der havde dansk som førstesprog, var forskellen på de to forsøgsbetingelser ikke signifikant.

Vi testede ikke deltagernes dansk, og vi kan se at deltagerne med serbokroatisk baggrund generelt læste langsommere end de danske deltagere (se tabel 2 og figur 1). Hvis man sammenligner de to gruppers gennemsnitlige læsetid under et for de to betingelser ved hjælp af en t-test for to grupper med samme varians, finder man at deltagerne med serbokroatisk baggrund $(N=12, M=2,30, S A=0,50)$ generelt læste signifikant langsommere end de deltagere der havde dansk som førstesprog $(N=12, M=1,64, S A=0,40)(t(22)=3,57, p=0,002, r$ $=0,61), o g$ at forskellen havde en middelstor effekt. Også dette resultat er forventeligt taget $\mathrm{i}$ betragtning af dansk er andetsprog for deltagerne med serbokroatisk baggrund. Men det afgørende for vores undersøgelse er at der var en interaktionseffekt mellem betingelse (subjektkoreferentialitet vs. objektkoreferentialitet) og sprogbaggrund (serbokroatisk som førstesprog vs. dansk som førstesprog), og at deltagerne med serbokroatisk baggrund læste sætninger med subjektkoreferentialitet signifikant langsommere end sætninger med koreferentialitet mellem ledsætningens subjekt og oversætningens oblikke led. Deltagerne med serbokroatisk som førstesprog fortolkede altså i udgangspunktet subjektet $\mathrm{i}$ en ledsætning anderledes end deltagerne med dansk som førstesprog.

Roberts et al. (2008) fandt at andetsprogsbrugere af hollandsk med enten tyrkisk eller tysk baggrund var forsinket ved læsning af anaforer når der var to mulige referenter i spil, uanset sprogbaggrund. Deres konklusion var at det ikke var førstesprogets type, men derimod det forhold at der var tale om andetsprogsbrugere, der var årsag til den forsinkede læsning (målt ved eyetracking) sammenlignet med førstesprogstalerne. Roberts et al.s undersøgelse og vores undersøgelse er imidlertid ikke direkte sammenlignelige. For det første var sætningsopbygningen i stimuli forskellig i de to undersøgelser. Roberts et al. brugte flere helsætninger i hvert enkelt eksempel, og referencen skulle vurderes på tværs af en helsætningsgrænse; i vores undersøgelse blev de to potentielle referenter nævnt i ledsætningens oversætning. Miltsakaki 
(2002) peger på nødvendigheden af at skelne mellem bestemmelse af hvad anaforer refererer til på tværs af helsætningsgrænser og inden for en helsætning; i det sidste tilfælde spiller verbernes semantik en langt større rolle end i det første. I vores undersøgelse var oversætningen ens i de to forsøgsbetingelser, og det temporale mens lagde op til en meget neutral sammenhæng mellem de to begivenheder som blev omtalt i oversætningen og i ledsætningen. For det andet forblev sætningerne tvetydige i Roberts et al.s (2008) undersøgelse. Læserne havde altså al mulig grund til at lade blikket dvæle ved eller vende tilbage til området med anaforen fordi de måtte beslutte sig for hvilken referent der var mest sandsynlig givet sætningernes struktur. I vores undersøgelse ledte resten af sætningen efter anaforen læserne i retning af en bestemt tolkning. Så en forsinkelse i læsningen efter anaforen afslører en skuffet forventning når læseren $\mathrm{i}$ udgangspunktet har lagt sig fast på en bestemt tolkning. Derfor er det sandsynligt at vores undersøgelse tydeligere viser betydningen af den typologiske forskel på sprogene end Roberts et al.s undersøgelse, men det bør undersøges ved forsøg med de samme danske sætninger og andetsprogsbrugere med førstesprog af forskellige typer.

En svaghed ved vores undersøgelses stimuli er at det ikke i alle tilfælde var muligt at lave sætninger hvor det var verbalet der sandsynliggjorde at ledsætningens subjekt var koreferentielt med enten subjektet eller det oblikke led i oversætningen. Fx er hvisker i sætningen Lareren kigger på eleven, mens han hvisker til sidemanden i timen ikke nok til at bestemme om han er koreferentielt med lareren eller med eleven. Derfor valgte vi som sagt at beregne reaktionstiden fra det tidspunkt hvor deltagerne klikkede videre efter at have læst subjektet, til de klikkede videre fra det andet ord efter verbalet, og denne beregning er ens for alle deltagere.

I disse år kommer der mange mennesker med et andet førstesprog end dansk til Danmark i en sen alder. I vores undersøgelse valgte vi en gruppe som kom til Danmark efter pubertetens start, og som for størstedelens vedkommende er godt integreret i det danske samfund, netop for at se om sådanne sene indlærere der har været eksponeret for dansk længe (minimum 23 år), stadig har forståelsesproblemer der kan påvirke dem i dagligdagen. Det er en pointe at alle deltagerne i undersøgelsen forstod sætningerne; andelen af rigtige svar fra deltagerne 
med serbokroatisk førstesprog var stort set den samme som andelen af rigtige svar fra deltagerne med dansk som førstesprog. Men deltagerne med serbokroatisk førstesprog var altså både signifikant længere om at læse sætningerne og specifikt længere om at læse de sætninger hvor strukturen stred mod deres viden fra serbokroatisk. Der er her tale om en ganske lille forsinkelse i forståelsen som næppe spiller nogen stor rolle i dagligdagen, men dog kan medføre træthed, især hvis en forsinkelse ved dette sproglige træk, bestemmelse af anaforers reference, ledsages af andre forsinkelser i sprogforståelsen.

En øget viden om hvordan dansk afviger fra de nye danskeres førstesprog, og hvor dansk afviger fra typologisk stærke tendenser i verdens sprog, vil kunne bidrage til at styrke undervisningen i dansk som andetsprog og forhåbentlig forbedre indvandrernes muligheder for integration.

\title{
TAK
}

Artiklen bygger på Donna Prohics speciale ved Lingvistik, Københavns Universitet, med Elisabeth Engberg-Pedersen som vejleder. Vi vil gerne takke Mads Poulsen for hjælp med eksperimentet, to anonyme bedømmere, NyS' redaktion og ikke mindst deltagerne i eksperimentet. Alle udestående fejl og mangler hviler naturligvis på os.

\author{
Donna Eleanor Prohic \\ Københavns Universitet \\ just-donna@hotmail.com \\ Elisabeth Engberg-Pedersen \\ Institut for Nordiske Studier og Sprogvidenskab \\ Københavns Universitet \\ eep@hum.ku.dk
}




\section{LITTERATUR}

Abbas, A. K. 1995. Contrastive analysis: is it a living fossil? International Review of Applied Linguistics in Language Teaching 33(3). 195-215. DOI: 10.1515/iral.1995.33.3.195.

Bailey, N., C. Madden \& S. D. Krashen. 1974. Is there a "natural sequence" in adult second language learning? Language Learning 24. 235-243. DOI: 10.1111/j.14671770.1974.tb00505.x.

Banathy, B., E. Trager \& C. Waddle. 1966. The use of contrastive data in foreign language course development. A. Valdman (red.), Trends in language teaching, 35-56. New York, NY: McGraw-Hill.

Carminati, M. N. 2002. The processing of Italian subject pronouns. Ph.d.-afhandling. University of Massachusetts Amherst, ProQuest Dissertations Publishing, UMI no. 3039345.

De la Fuente, I. \& B. Hemforth. 2013. Topicalization and focusing effects on subject and object pronoun resolution in Spanish. J.C. Amaro, G. Lord, A. de Prada Perez \& J.E. Aaron (red.), Selected proceedings of the 16th Hispanic Linguistics Symposium, 27-45. Somerville, MA: Cascadilla Proceedings Project.

De la Fuente, I., B. Hemforth, S. Colonna \& S. Schimke. 2016. The role of syntax, semantics, and pragmatics in pronoun resolution: a cross-linguistic overview. A. Holler \& K. Suckow (red.), Empirical perspectives on anaphora resolution, 11-31 (Linguistische Arbeiten 563). Berlin: De Gruyter. DOI: 10.1515/9783110464108-003.

Dulay, H. C. \& M. Burt. 1974. Natural sequences in child second language acquisition. Working Papers on Bilingualism 4. 71-98. DOI: 10.1111/j.1467-1770.1974.tb00234.x.

Dulay, H. C., M. K. Burt \& S. D. Krashen. 1982. Language two. Oxford: Oxford University Press.

Ellis, R. 2015. Understanding second language acquisition, 2. udg. Oxford: Oxford University Press.

Gass, S. M. \& L. Selinker (red.) 1983. Language transfer in language learning. Rowley, MA: Newbury House.

Geva, E. 2014. Introduction: the cross-language transfer journey - a guide to the perplexed. Written Language \& Literacy 17(1). 1-15. DOI: 10.1075/wll.17.1.01gev.

Givón, T. 1983. Topic continuity in discourse: an introduction. T. Givón (red.), Topic continuity in discourse: a quantitative cross-language study, 1-42. Amsterdam: John Benjamins Publishing Company. 
Hemforth, B., L. Konieczny, C. Scheepers, S. Colonna, S. Schimke, P. Baumann \& J. Pynte. 2010. Language specific preferences in anaphor resolution: exposure or Gricean maxims? S. Ohlsson \& R. Catrambone (red.), Proceedings of the 32nd annual conference of the cognitive science society, 2218-2223. Portland: Cognitive Science Society. (https://escholarship.org/uc/item/8kq1b40b)

Keating, G. D., B. VanPatten \& J. Jegerski. 2011. Who was walking on the beach? Anaphora resolution in Spanish heritage speakers and adult second language learners. Studies in Second Language Acquisition 33. 193-221. DOI: 10.1017/S0272263110000732.

Kellerman, E. \& M. Sharwood Smith (red.) 1986. Crosslinguistic influences in second language acquisition (Language Teaching Methodology Series). New York, NY: Pergamon Press.

Krashen, S. 1982. Principles and practice in second language acquisition (Language Teaching Methodology Series). Oxford: Pergamon Press.

Lado, R. 1957. Linguistics across cultures: applied linguistics for language teachers. Ann Arbor, MI: University of Michigan Press.

Leko, N. 1989. Case of noun phrases in Serbo-Croatian and case theory. Folia Linguistica 23(1-2). 27-54. DOI: 10.1515/flin.1989.23.1-2.27.

Lenneberg, E. H. 1967. Biological foundations of language. New York, NY: John Wiley.

Littlewood, W. T. 1984. Foreign and second language acquisition: language acquisition research and its implications for the classroom. Cambridge: Cambridge University Press.

Miltsakaki,E. 2002. Toward an aposynthesis of topic continuity and intrasentential anaphora. Computational Linguistics 28(3). 319-355. DOI: 10.1162/089120102760276009.

Odlin, T. 1989. Language transfer: cross-linguistic influence in language learning (The Cambridge Applied Linguistics Series). Cambridge: Cambridge University Press. DOI: 10.1017/CBO9781139524537.

Peirce, J. W. 2009. Generating stimuli for neuroscience using PsychoPy. Frontiers in Neuroinformatics 2(10). 1-10. DOI: 10.3389/neuro.11.010.2008.

Roberts, L., M. Gullberg \& P. Indefrey. 2008. Online pronoun resolution in L2 discourse: L1 influence and general learner effects. Studies in Second Language Acquisition 30. 333-357. DOI: 10.1017/S0272263108080480.

Runner, J. T. \& A. Ibarra. 2016. Information structure effects on null and overt subject comprehension in Spanish. A. Holler \& K. Suckow (red.), Empirical perspectives on anaphora resolution, 87-112 (Linguistische Arbeiten 563). Berlin: De Gruyter. DOI: 10.1515/9783110464108.

Skinner, B. F. 1957. Verbal behavior. New York, NY: Appleton Century Crofts. 


\section{BILAG: MÅLSÆTNINGER I EKSPERIMENTET}

S1a: Faren vinker til sønnen, mens han kører forbi legepladsen en formiddag.

S1b: Faren vinker til sønnen, mens han leger på legepladsen en eftermiddag.

S2a: Kvinden hilser på kassedamen, mens hun betaler for varerne på båndet.

S2b: Kvinden hilser på kassedamen, mens hun scanner varerne på båndet ind.

S3a: Balletdanserinden ser på rengøringskonen, mens hun øver sig ved barren.

S3b: Balletdanserinden ser på rengøringskonen, men hun støvsuger gulvet i studiet.

S4a: Politimanden får øje på tyven, mens han tilkalder assistance fra nærmeste politistation.

S4b: Politimanden får øje på tyven, mens han dirker låsen til kontoret op.

S5a: Læreren kigger på eleven, mens han underviser i matematik om onsdagen.

S5b: Læreren kigger på eleven, mens han hvisker til sidemanden i timen.

S6a: Eleven stiller læreren et spørgsmål, mens han skriver stil i dansktimen.

S6b: Eleven stiller læreren et spørgsmål, mens han retter stile på kontoret.

S7a: Tanten kalder på sin lille niece, mens hun steger bøffer i køkkenet.

S7b: Tanten kalder på sin lille niece, mens hun leger med dukker udenfor.

S8a: Sygeplejersken snakker med kvinden, mens hun stikker en kanyle i en stor åre.

S8b: Sygeplejersken snakker med kvinden, mens hun hviler sig i hospitalssengen på stuen.

S9a: Dommeren kigger på den anklagede, mens han afgør dommen i sagen.

S9b: Dommeren kigger på den anklagede, mens han græder voldsomt over dommen.

S10a: Manden returnerer græsslåmaskinen til naboen, mens han takker for lånet af den.

S10b: Manden returnerer græsslåmaskinen til naboen, mens han ligger i hængkøjen i haven.

S11a: Moren kigger over på den lille pige, mens hun brænder affald i baghaven.

S11b: Moren kigger over på den lille pige, mens hun savler ned ad hagesmækken.

S12a: Kassemedarbejderen ringer efter chefen, mens han scanner varer ind i kasseapparatet.

S12b: Kassemedarbejderen ringer efter chefen, mens han efterser nogle regnskaber på kontoret.

S13a: Sønnen kalder på faren, mens han leger på klatrestativet i gården.

S13b: Sønnen kalder på faren, mens han betaler for benzin på tankstationen.

S14a: Patienten takker lægen, mens han udskrives fra Hvidovre Hospital.

S14b: Patienten takker lægen, mens han tilser patienterne i akutmodtagelsen. 
S15a: Taxachaufføren taler til passageren, mens han kører over for rødt i lyskrydset.

S15b: Taxachaufføren taler til passageren, mens han læser i en brochure på bagsædet.

S16a: Damen hilser på den lille pige, mens hun ryger en cigaret på verandaen.

S16b: Damen hilser på den lille pige, mens hun sjipper på fortovet foran huset.

S17a: Lægen undersøger patienten, mens han dikterer resultaterne til sekretæren.

S17b: Lægen undersøger patienten, mens han ligger bevidstløs på båren.

S18a: Manden nikker til postbuddet, mens han slår græs i forhaven om sommeren.

S18b: Manden nikker til postbuddet, mens han afleverer en lille pakke i postkassen.

S19a: Bedstefaren sidder ved siden af sit barnebarn, mens han ryger pibe i sofaen.

S19b: Bedstefaren sidder ved siden af sit barnebarn, mens han farvelægger dyr i malebogen.

S20a: Cyklisten råber ad bilisten, mens han cykler over den trafikerede vej $\mathrm{i}$ byen.

S20b: Cyklisten råber ad bilisten, mens han dytter ad en gruppe børn i fodgængerfeltet. 